\title{
Global digital genre-communication forms in the process of flow to local Polish memosphere: the case of Facebook art memes*
}

\author{
ANNA GUMKOWSKA*, PIOTR TOCZYSKI** \\ * Polish Academy of Sciences: Institute of Literary Research \\ ul. Nowy Świat 72, 00-330 Warsaw, Poland \\ E-mail: annagumkowska00@gmail.com \\ ** Institute of Philosophy and Sociology, The Maria Grzegorzenske University, \\ ul. Szcréslitwicka 40, 02-353 Warsaw, Poland, \\ E-mail:piotr.tocryski@opi.org.pl
}

\begin{abstract}
We analysed the mechanisms generating specific genres in the digital network and described the phenomena which result in shaping new forms of modern communication genres. New digital genre-communication forms are exemplified by Facebook "art memes", which should be studied from two perspectives: literary research and social studies. The art of painting remediated in digital forms of so-called "memes" illustrates the global flow from the Western centre to the Eastern semi-peripheries of digitalizing Euro-Atlantic civilization. We applied analytical framework consisting of six criteria: sender, recipient, message, code, context and contact. Our conclusion is that the process of global-local flow, as exemplified by Facebook art memes, results in local enrichment of the global medium and content.
\end{abstract}

Key words: social media, digital genres, memosphere, memes, global media, local expression, Poland

\footnotetext{
* Anna Gumkowska's contribution to the text is the result of a grant headed by her at the National Science Centre. Grant number 2013/11/N/HS2/03560 237081: "A Mechanism for Creating New Web Genres on the Internet: Facebook, Twitter, Pinterest-Memes and Facebook art memes". This paper was written with a financial support from the National Science Centre.
} 


\section{INTRODUCTION: OUR RESEARCH QUESTIONS}

The aim of this study was to analyse the local dimension of global Facebook "art memes". To achieve this goal, we asked three research questions.

Firstly, what modifications, no doubt associated with earlier models, have been subjected to the new forms of communication? When we consider changes of the medium and changes in the structure of the message, a number of specific issues emerge: to what extent can we speak of new online genres? How should the new forms of communication be reconciled with the tradition of genres? What new genre determinants need to be taken into account? Which ones need to be omitted so that to recognize their different specifics, i.e. a new, different perception to communication and a response within it?

Secondly, how do technological capabilities in conjunction with the activities of Facebook network users and their past experience allow creating new forms of communication both in a group and on an individual level?

Thirdly, viewing Facebook art memes through the prism of global social processes leads to questions about the transfer or journey of the theme and especially the form. Polish reception is therefore confronted with the digitalizing Western memosphere and especially with its subsphere visible within the "walled garden" of Facebook.

We describe some mechanisms and processes that are responsible for generating new digital-genre communication forms - exemplified by Facebook art memes.

\section{OUR METHODOLOGICAL PERSPECTIVE: GLOBAL FLOW OF GENRES}

The presented research project is a detailed analysis of the issues of organizational forms of texts on the network as visible on Facebook: (1) formal organization, understood as a publishing frame, which provides for specific visual organization of the content, (2) organization of content, and (3) organization of social circulation enabling dialogue between the sender and the audience, creating a social bond, implying an agreement, sometimes even community activities. Therefore, three research areas are subjected to our "X-rays": the use of communication techniques (including in the technological dimension), the construction of distribution and opinion-sharing networks. 
Our project required a detailed analysis of multimedia writings published on the most popular communication platform. Facebook, having many features and modes of operation, has also become a field of formation of many versions of one genre: memes. While many versions of memes appear on Facebook, Twitter and Pinterest, , as well as on Instagram or within one-toone digital communication, these platforms are only places of distribution, not of the creative processes as such. Facebook and other current digital platforms emerged in the United States, but they are perfectly suited to the communication needs of customers in other countries (Gumkowska, Toczyski, 2016). The American origin of Facebook and the memosphere clearly suggest that globalization is one of the drivers of new genres in the Polish cyberspace. Polish users acquire these forms of communication with a slight delay, which suggests the U.S. market and digital parts of American society have leading role in the emergence of the new media. It is therefore a phenomenon of Westernization, one of the aspects of globalization in today's world, a clear direction of which - West to East - cannot be overlooked when we describe the international and transnational social process of diffusion of new technologies and the transfer of the related forms of communication. These are exemplified by Facebook art memes in our study.

While the origins of genre studies date back to ancient times, the information revolution of recent decades has brought a number of changes in this respect. There are no more permanent genre indicators, only parts of structural forms that make up short connections, and then migrate further. On the one hand, these changes show the anachronism of substantial amount of research, oriented towards the existence of permanent genre types even in digital space. On the other hand, they allow us to appreciate the wealth of the new forms and their momentary applications, based on personal, individual awareness of online users. Using a metaphor, we could say that before the digital multimedia age, genres were like stalactites, and today, they are more like a pyrotechnic show. A thorough analysis of the dynamic genre-evolving processes on these sites will lead to new conclusions about contemporary literary culture and the digital society.

Our research certainly fits into the current modern genre theory, which is a branch of science attempting to unify the research perspectives on artistic and non-artistic genres. Within modern media theory of genres, genres consist of factors such as: repeatability of the combination of tricks, targeted communication and dependence of the genre on communication technology (medium). While topics such as blogging seem to be sufficiently elaborated on from the perspective of literary and social studies, the budding genre of memes is a new ground, requiring analysis. We decided to use the word "blogosphere", describing the sphere of blogging, and apply it to the sphere of meme creation and distribution, naming it the "memosphere". Facebook art memes, on which we focus, are part of both local and global memospheres. 
Capturing the protean nature of modern genre forms of communication occurring on the Internet (websites and mobile) is not an easy task. It requires great flexibility and continuous observation. It also requires an innovative research workshop. On one hand, it is a transfer of information (but not knowledge) possessed still mostly by business onto the testing ground of electronic discourse. On the other hand, it is a use of this knowledge for in-depth analysis of literature. The tools used will combine existing literary research experience with new communication situations in the world of new technologies. Multimedia writings and pictures on Facebook should be examined both in terms of their technological capabilities and semiotic aspects.

\section{STATE OF KNOWLEDGE ON DIGITAL GENRES}

In the traditional sense, genre science (genology) is defined as a branch of poetics dealing with types and literary genres, examining definitions of these concepts, their forms of existence, descriptions of structure, typology or systematization of literary material, as well as the historical development of genres, historical systems of genres, layers of genre awareness and the use of names and genre concepts (Cudak, 2007). The term "genology" appeared only in 1920 in the work of a comparatist and literary research methodologist Philippe van Tieghem, although it is assumed that this kind of reflection had gained the status of science much earlier, in the second half of the nineteenth century, through the work of the critic Ferdinand Brunetière (Skwarczyńska, 1966).

The different understandings of genology emerging throughout history can be divided into: genology until nineteenth century as an universalist stage, genology in late nineteenth and early twentieth century, when the literary science was developing as a separate branch of science (Gajda, 2001). The origins of Polish genology, which made a substantial contribution to the development of science (conferences, symposia, collections) was usually associated with the activities of Stefania Skwarczyńska.

Further developments in the so-called New Genre Theory (Balcerzan, 1999) occur in parallel and different directions, on the one hand, by developing research of new literary forms (Grochowski, 2000), on the other hand, by including par literary and utility texts in the range of genre researcher's interests. New faces of genology were also created, such as know media genology, intersemiotic genology. Researchers of linguistic genology have slightly different positions (Witosz, 2002). 
There is a growing collection of hybrid texts that cannot be placed on a taxonomic grid. Some researchers wonder whether this means that the genres are not inevitably doomed (Balbus, 2000). Still, modern genre theory evolves (Balcerzan, 2000). The Modern Genre Theory is a discipline understood more broadly than traditional genre science, which, as a rule, is limited to literary genres. Proponents of the Modern Genre Theory postulate stretching the concept of "genre" to encompass the whole sphere of social communication situations. After Bachtin, they argue that "we speak using only certain genres of speech... Genres of speech are given to us in almost the same way as the native language, which we use without difficulty even before the theoretical mastery of grammar" (Bachtin, 1986, p. 373). In this sense, modern genre science deals with every utterance, both printed by a prestigious publishing house and written on the Internet by an anonymous user. As Bolecki wrote, understanding of the genres as solid forms referring to the new media must turn into situational genres (Bolecki, 2007, p. 217).

As can be seen from the above discussion, the term "genre" entails many historical, terminological and ideological complications, which will be analysed during this project. According to its earlier (prior to Bachtins') definitions, genre required durability, permanence, constitution of individual parameters and awareness of the existence of both the sender and the recipient to exist, figuratively speaking, crystallized as the stalactite: a form which is relatively stable over time. However, the Internet does not crystallize genres. Genre is not a stalactite, but rather a pyrotechnic show, because all forms of communication are highly dynamic processes of change, are more fleeting and momentary, are closer to types of speech, are not covered in the previous taxonomies and are created in specific communication situations. The variability of the forms of online communication can be easily illustrated with the example of blogs or Facebook art memes, which played a completely different role at first. Blogs have grown directly from the specific technological tradition which came to Poland from the West (Winer, 2004). The presence of blogs on the Polish web space is a manifestation of the afore-mentioned process of Westernization.

The internet exerts a growing influence not only on literary practices, but also on social, economic, cultural and even civilizational processes in general. Texts created online attract increasing attention from researchers. However, to what extent can the current state of knowledge be used to study new forms produced by the information society, otherwise referred to by sociologists as the new society, media civilization, digital society, network and e-society?

Multimedia writings are predominantly composed of functional texts that emerge outside of literature and become literature only in exceptional cases. Memes and Facebook art memes in general are not objects of aesthetic perception, but the social means of interpersonal 
communication in the dimensions of the ethical, emotional and reference (Lejeune, 2007). If there is any way to incorporate them into literature, it is only by providing them with the terminology of applied literature as defined by Stefania Skwarczyńska (1932). However, "genre systems are governed, like other social institutions, by the force of inertia (which secures the continuity of facilitating communication) and the force of change (literature lives only as long as it transforms expectations of the readers). Literature should not be understood as an autonomous whole with post factum attempts to tie to the social phenomena. Its independence is very relative, because she is primarily a social system.” (Lejeune, 2007, p. 57, 92) Therefore, memes and Facebook art memes are treated as an important and significant social phenomenon that also requires analysis with the tools available for the science of literature, including genre theory.

The thesis of the existence of genres in the Internet has been unanimously adopted and popularized although there is no definition that would allow clear identification of what an online genre is and on what basis it is to be isolated. It is especially important from the perspective of the past 20 years of the emergence and subsequent mutating of online communication forms. All modern genre research on the Internet undertaken so far has shown the difficulty of reconciling the different orders of current genre knowledge with online communications practices. Researchers dealing with multimedia writings are struggling with the definitions of the genres, their implementations and classifications (Gumkowska, Maryl, Toczyski, 2009).

To describe the difficult nature of the world wide web, genre researchers usually rely on the concept of remediation proposed by media experts Jay Bolter and Richard Grusin (2000). Remediation is the logic "according to which new media are transforming the earlier media forms" (Bolter, Grusin, 2000, p. 273). No new media form is born from the scratch, the researchers say, all new media technologies rely on old technology transformation, modernization and addition of the newest media technologies. Each new form is therefore "a representation of one medium in another".

In addition, genres can be understood mainly by reference to their social aspects (Hare et al., 2007; Trammel et al., 2006; Wojcik and Dryll, 2008; Gill, Nowson and Oberlander, 2009; Cywińska-Milonas, 2002). The book entitled Liternet.pl (Marecki, 2003) was the first anthology of electronic literature in Poland. However, the author focused on literary societies, the problem of hypertext, blogs and copyright websites. The issue of modern genres was not raised. Similarly, in Literature and the Media After 1989 (Hopfinger, 2010) you can find an entire chapter devoted to electronic literature, but no resolution of modern genre issues. Researchers analysing the new communication phenomena often turn to tools of poetics media (Szczęsna, 2007) or to Intersemiotics (Balbus et al., 2004). The modern genre theory called for the research stage of 
online texts, mainly blogs. This is evidenced by the recent work of Marta Więckiewicz, who analyses blogs from a multimedia modern genre standpoint (Więckiewicz, 2012), or by the works of Maciej Maryl (2010).

Genre classification is important not only for purely theoretical but also for practical reasons. There are ongoing projects creating search engines which automatically identify genres to facilitate the orientation of online surfers on the net. This is not an easy task due to insufficient standardization of websites, lack of modern genre research conducted on multimedia writings and new digital competence of the audience, which does not stem from historical knowledge. Referring to the definition of the medium by McLuhan (1994), Danah Boyd (2006) proves that some media have different distribution channels, such as television, which can be accessed through satellites, cable connections or radio waves. The Internet, according to this researcher, is a multimedia channel that reveals the processes of media convergence. One of the media in the context of the Internet is the blog and meme. Thus, the researcher does not treat blogs as a genre, but as a medium.

Internet users also actively engage in discussions concerning online genres, unfortunately without much success. The definitions generated by them in American literature are referred to as Meta-Genre (Giltrow, 2001). However, from the point of view of literary experts, it does not seem right to use the term Meta-Genre in this sense or to define genres only by reference to user awareness. This is because there are usually standard rules operating as a collection of unwritten and even unconscious rules and regulations, which govern a given text.

\section{STATE OF KNOWLEDGE ON THE MEMOSPHERE}

Memes are the viral part of online culture, and can gain so much attention that they spread into mainstream popular culture (Chen, 2012). Memes are also a type of an online social game. Their definition is expanding: they can be funny images, captured at the right moment, with a comment, or short animations in the form of GIF files, or videos shared by social media users. Internet users often refer to them as online phenomena, good or catchy ideas, humour, cutting retorts, virals, graphic commentary, graphics with captions (Hatalska, 2013). What is interesting is that references to comic books are rare, as they are associated with a story told over several stages, while a meme captures just a single point in time without any continuation.

What are the origins of memes? We are not going to argue that authors of memes are aware of their association with the Greek $\mu i \mu \nu \dot{\eta} \sigma x \omega$. Then search for etymology of modern 
expressions in the Antiquity often ends in a blind alley (Shifman, 2013), but in this case a short analysis of the concept will allow us to highlight the characteristic features of online memes.

Once again, we should stress that in general reception of the word "meme" is a derivative of "memory". The name did not appear on the Internet thanks to academic discourse or debate on etymology or the Dawkins theory. It emerged as a result of economics of online communication and the need to find new names for a new communication practice (Grzenia, 2006).

However, if we wish to consider the Greek root, we have two options. Mem could be derived either from the verb $\mu \mu \nu \dot{\eta} \sigma \varkappa \omega$, which is related to memory and means "to memorize, to remind" (Jurewicz, 2001, p. 58) and gave the name to the Greek goddess Mnemosyne, the mother of the nine muses, or from the verb $\mu \mu \varepsilon \varepsilon \mu \mu$ l meaning "to imitate, to present, to replicate" (Jurewicz, 2001, p. 57). On the one hand, it is a message memorized in communication, on the other, it can be imitated or replicated. These meanings can be placed in a certain hierarchy: when it comes to its existence on the Internet, memorizing a meme plays the most important role (the meme must be interesting enough so that the innovative combination of an image with a comment is easily memorable and the users want to share it with their friends), while imitating and replicating (independent creation of new versions) is secondary to that.

In the world of science, the word meme was first used by an Austrian physicist Ewald Hering in 1870, who derived it from $\mu \mu \nu \dot{\eta} \sigma x \omega$ (Shifman, 2013, p. 363). Next, it was used by a German biologist Richard Semon to describe memory trace in 1904 (Semon, 1909). Later, the term appears in a 1927 book entitled The Life of the White Ant by a Belgian playwright and essayist Maurice Maeterlinck (Laurent, 1999). However, scholars associate the concept mainly with the theory of Richard Dawkins (1996).

Numerous researchers (Knobel, Lankschear, 2007) have tried to recontextualize Dawkins' idea of a meme in the context of digital culture through analysis of online memes. Limor Shifman, who tries to reconcile both orders (Dawson's theory and online practice), starts with a famous statement: "Memes are a pain. Or so at least a glance into the world of academic literature would suggest”' (2013, p. 362).

Description of the heated debate over Richard Dawkins' The Selfish Gene of 1976 would exceed the limits of this publication. Further discussion requires the adoption of a general definition of online memes. The broadest and most encompassing definition is provided by Limor Shifman. In her book entitled Memes in Digital Culture she defines memes as "digital content units with common characteristics of content, form, and/or stance, created with awareness of each other, and circulated, imitated, and transformed via the Internet by many 
users." (2013, p. 27). Shifman differentiates memes from virals, analyses the reasons for their success or failure and categorizes them. She believes that memes are a new way of participating in democratic political life and considers them "agents of globalisation".

Among the Polish proposals, the definition put forward by Wiktor Kołowiecki seems similar to the ones quoted above: „An online meme is a digitized unit of information (text, image, video, sound) distributed online, which is copied, processed and published in such processed form on the Internet" (Kołowiecki, 2012). The author presents the concept from the perspective of cultural studies.

Some of the noteworthy Polish works on memes include Niecne memy. Dwanaście wylktadów o kulturze Internetu (Kamińska, 2011) and several articles: Memy internetowe jako nowy jezylk internet by Wiktor Kołowiecki (2012), Memy internetowe - tworzenie, rospowszechnianie, znaczenie społeczne by Marta Juza (2013), papers by Adam Walkiewicz or Demotywatory. Graficzne makra w komunikacji $i$ kulturze by Sieńko (2009). An approach from the perspective of media studies can be found in works by Marta Juza, who focuses on the functioning of memes on the basis of mechanisms similar to those governing gossips, urban legends, rumours or jokes. She also refers to Diagnoza Internetu (Milewski, Toczyski, 2009) and the World Internet Project 2012 (Toczyski et. al., 2012), which show that "only some Internet users use the web in an active way (in the study they are called Authors). Most users (referred to as Observers and Consumers) use the web as a source of information and method of maintaining contacts with other people. Authors actively participate in the life of online forums, write blogs, comment on current events and publish the results of their own work (including memes). It should be stressed that all creative online work is posted mainly by young people... We could presume that they would pursue their passions even without the Internet or, more generally speaking, without digital technologies, although with them, their activity becomes much easier" (Juza, 2013, p. 53).

\section{FACEBOOK AS AN ORGANIZATION FOR SOCIAL CIRCULATION OF MEMES}

Facebook is a machine created for social networking, but also for social distribution of content including memes. The entire system, its connections, mutual contents, algorithms - they all aim to deliver information and opinion to the largest possible number of recipients. The aim and its mechanism is simple: to display and share interesting messages to encourage users to return to the website or mobile application - if not make them connected permanently - because they know that they will find interesting content, adjusted to their needs, which has already been proofed by their friends. They do not have to search through thousands of messages to get to 
those that deserve their attention. This is an advantage of Facebook feed over Google. It is primarily a strictly confidential, well-protected algorithm of Facebook that decides which posts should be displayed and in what order. It is not known for how long the news feed should work to capture individual needs and interests of its users, to respond with the most interesting posts selection. Its adjustments seem to be dynamic and real-time.

Allegedly, the algorithm takes into account over fifty different factors, the most important ones being: with whom the user interacts most often, which posts he/she "likes" or comments on, whom he/she sends private messages to or chats with, which links he/she usually clicks. Very often, recipients are not aware of how this system works and that the information in their profiles is automatically filtered. Dynamic changes of posts shown in the news feed with peritexts illustrating their chronology conceal the interventions of an intermediary who shapes the reality we see and access. It is quite obvious that posts with texts and images are rated higher by the algorithm. Because this fact is concealed, the "virality of information" grows especially towards pieces of logo-visual content. Posts appear relevant and credible - because they are recommended by one's friends. Specific senders and recipients are unaware that they are assigned to a one or another "filter bubble".

Information published on one profile is automatically posted within the news feed of one's friends and fans. Given its current reach, this platform is like an Internet within the Internet - a huge network of connected users who can interact with each other as long as they remain within the "walled garden" of Facebook. So the entire system inside the website works towards internal content distribution and prefers such information and opinion spread over redirecting to the external websites. Participants of such communication recommend posts to each other. Distribution works on several levels: in a systemic way (as a new version of blogroll, but multiplied) and through virals (as in the case of memes), based on recommendations.

There is a hidden automated intermediary present in the Facebook communication process, which is constantly modified - although not necessarily improved from the user experience perspective. In such digital environment, narrow topics are distributed within a group of interested users, while universal themes can count for a wide reach. But the interest in the given post is short-lived, especially in the case of memes. The life of a message in this communication-intense environment is becoming shorter and shorter. However, there are mechanisms analogous to blogs which should be taken into account within the analysis of Facebook. It is the participation of other media, which are looking for interesting information on this platform. Facebook serves as cross-media tool for monitoring social interest and raising the 
status of posts by quoting them and treating them as a source of information and opinion forming, not just entertainment.

We decided to describe Facebook in a more detailed way than it usually is considered in such studies. It is because of the platform's significance for a new digital genre-communication forms.

\section{THE INNER STRUCTURE OF “ART MEMES”}

As we have already mentioned, within the "walled garden" of Facebook there is a sub-category of memes called "art memes". These are memes based on works of known artists. Some of them enjoy high popularity on Facebook and can have ca. 1.2 million likes, which is comparable to big, professional websites: https://www.facebook.com/classicalartmemes/?fref=ts. Upon closer look, art memes also have vulgar and hateful versions - and not only those. To find out more, one can visit the following websites: https://www.facebook.com/ClassicaIArtMemes/?fref=nf; https://www.facebook.com/groups/RenaissanceAnonymousArt;

https://www.facebook.com/Artmemephoto; https://www.facebook.com/medievalartmemes. These fanpages illustrate the existence of a global English-language space for "art memes". Its local, Polish version, which we will analyze in detail, is called "Sztuczne Fiołki" ("Artificial Violets”). Its author himself considers Facebook art memes to be new forms of expression (Tengowska, 2013) and describes them as: "free voice of a pseudo-historical comical- tragic magazine which insures liberty [concealed leftist option]" or as "classical paintings with absurd inscriptions" (Klimowicz, 2014). What we know is that the author comes from Białystok, is a graduate of English Studies and studied fine arts in the United States (Klimowicz, 2014). The name of the profile ("Artificial Violets") stems from the word "art" for "Artificial" to the Letters with Violet by K.I. Gałczyński (Klimowicz, 2014). Such composition of global digital medium and its genres with the local language and cultural space - based in semi-peripheries of Europe illustrates international and cross-cultural transatlantic flow of new media as correlated with local experience.

Global socio-cultural processes are of our interest, but we look at the phenomenon in more detailed way in order to describe the genre-communication form of Facebook art memes in terms of poetics. We are interested in the inner organization of content in the context of a communication setting by reference to the sender, recipient, message, code, context and contact projected within the text, which are the basic elements of communication identified by Roman Jakobson. This will allow us to identify recurring principles characteristic of the genre, and the 
accompanying style of both single messages and the entire genre as such. Repeatability at a certain level (usually at the level of structure) is the basic condition for defining a new genre, even in the case of such dynamic media as the Internet. After Aleksandra Okopień-Sławińska we could say that: "on the one hand, each statement (...) proves the existence of a sender outside that message, just as every product proves the existence of its maker, and, on the other hand, presents the sender through its characteristic, inner semantic organization" (Okopień-Sławińska, 1987, pp. 31-32). Moreover, "each use of language corresponds to some social experience. The implicated metalinguistic message about the manner in which language is used in the given text, proves the existence of a sender as the provider of certain social practice" (Okopień-Sławińska, 1987, p. 34).

The fanpage we analyze is an example that even in the mass media one can draw the attention of a recipient used to popular entertainment to art. The author provides works of great artists with bubbles with his own commentary. He says that "the violets" (this is what he calls the individual Facebook art memes micro-posts) are created with a specific recipient in mind: a person dealing with literature, broadly understood humanities or culture" (Klimowicz, 2014). Moreover, he adds that he wants to remain anonymous, because "the Violets do not need an Author (capitalised). As you can see, they are doing just fine without him" (Tengowska, 2013).

\subsection{SENDER}

The sender is exposed through the automated system (information on the sender is displayed by each Facebook art meme), but he does not manifest his/her existence in the text too much. The sender fulfils his role without unnecessary self-presentation. He does not refer to his private life, and any autobiographic elements are limited to presentation of content connected with the sender's interests and opinions. The sender is not present through information coming from the extratextual world - which, in the case of Facebook profiles, ensure credibility - but mainly through the message embedded in the communication. The sender is the main narrator, he sends information and decides on its form. But it is the message itself that constitutes a representation of the sender's views. The author's introduction in the form of a comment is much different from the recommendation typical of a blog. There are hardly any comments referring to the author's childhood memories, current family life or career. The sender tries to hide himself to highlight the topic, and to manifest his subjective point of view through that topic.

On the profile called "Sztuczne Fiołki", each image with a bubble is preceded by a microcomment, in which the sender pretends to take a neutral stand, as if coming from a different order of things; it provides metatextual information on the real author of the image and the relevant dates. Micro-posts are usually composed of four elements. The first element consists of 
the information on the sender, delivered by the system (1), followed by the author's comment (2) and an additional element in the form of an image or some other multimedia material (3). The last element, provided by the system, is the date of publication with comment and share options (4), so that users can engage in a dialogue with the author. Below, one will find an example from "Sztuczne Fiołki" - the micro-post refers to the social campaign called "Eat apples to spite Putin", propagated by the media after Russia's embargo on Polish fruit and vegetables in August 2014.

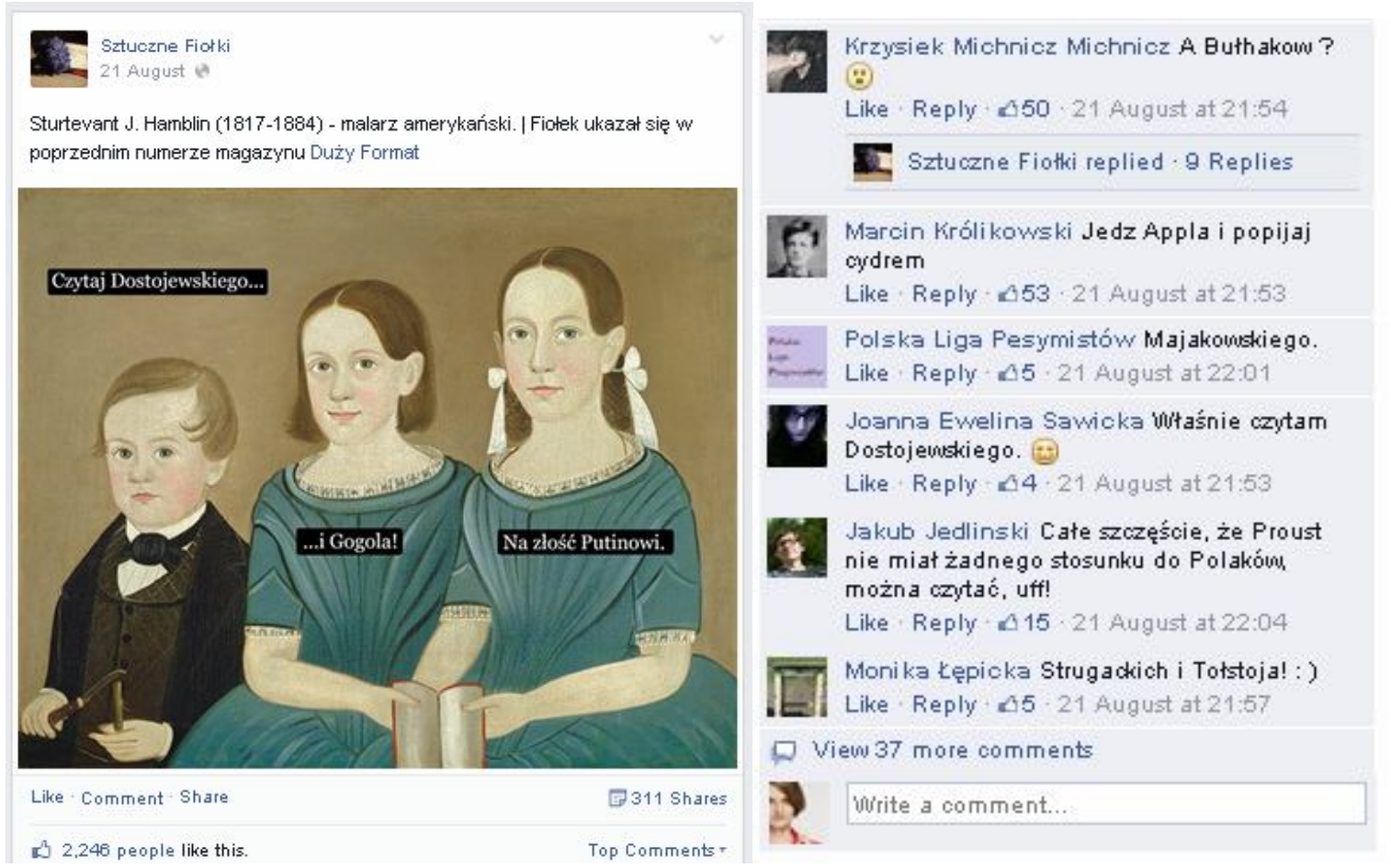

Fig.1. Meme published at:

https://www.facebook.com/SztuczneFiolki/photos/a.483789074973669.115138.483774998308410/8317033268489 07/?type $=1$ [access: May 2016]

The sender's metatextual micro-comment preceding the meme such as: "Sturtevant J. Hamblin (1817-1884) - American painter (the meme was published in the last issue of "Duży Format") informs the recipients of the desired semantic approach to the text, facilitating their interaction with and comprehension of the message. It is a signal suggesting a semantic game based on irony and comedy. It categorizes the message under an appropriate reading style.

A digression: Dorota Lagodzka points out that Facebook texts contain information about the author of the processed painting, but outside of the platform, the meme loses that information. Lagodzka writes: "Sztuczne Fiołki provides the authors of the paintings, but the users who share those memes elsewhere do not always do that. It is as if Sztuczne Fiołki had painted a given $19^{\text {th }}$-century landscape or a painting by Malewicz. The meme spreads in this form, 
with a new author. It is as if we considered a person quoting someone the author of the quote" (Lagodzka, 2014). Hence, a meme found outside of the Facebook platform is deprived of its typical publication framework (the text frame), which signals the proper interpretation of the Facebook art meme.

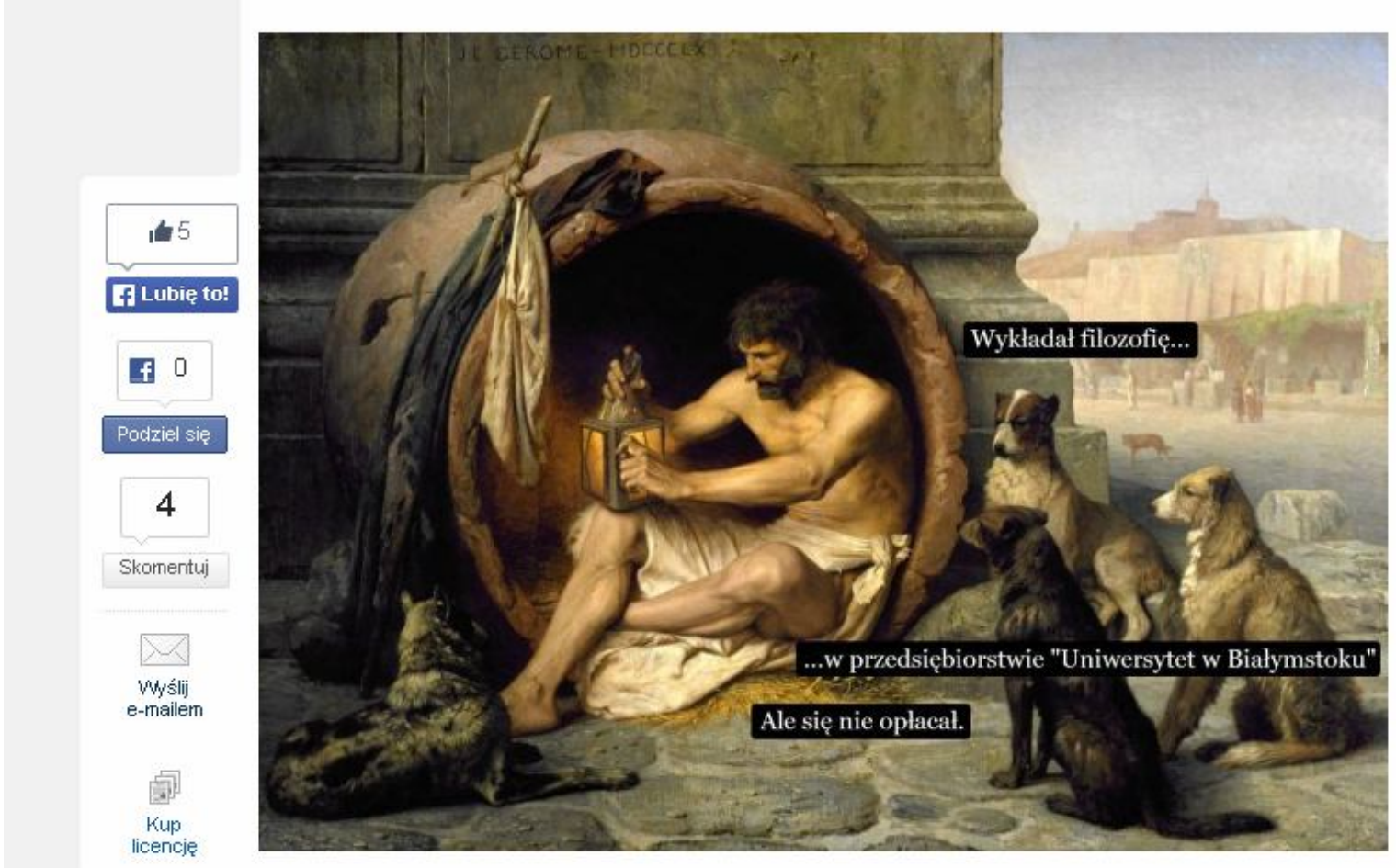

Fig. 2. Meme published at:

http://bialystok.gazeta.pl/bialystok/1,35241,15498803,Sztuczne_Fiolki_Mam_w_sobie_duze_poklady_wscieklosci. html [access: May 2016]

In the case of Facebook art memes, the sender appears on four levels: in the systemgenerated author information (1), in the author's micro-comment (2), in the attached logo-visual material (3), in the comments exchanged with recipients (4). So the sender is not the feature point here - the topic is. There is no author's ethos. But the sender is aware of the dialogue and community-building process, so he nurtures his relationship with the recipient, as shown by such posts as: "A goodnight meme for you. Tomorrow you will find Pires with the Nocturnes at the National Philharmonic as part of the "Chopin and his Europe" festival" or "To all you night owls: Jean-Philippe Rameau (1683-1764), a French composer and music theorist from the baroque era. Ralph Kirkpatrick (1911-1984), an American musician, harpsichordist and musicologist". The sender tries to moderate the recipient's actions. In what form is the sender present in the logo-visual message? In the case of Sztuczne Fiołki, the comments placed on known paintings consistently covey the sender's worldview and attitude.

The sender's attitude to the world is reconstructed through the cyclical nature of the posts. The sender of the logo-visual texts on "Sztuczne Fiołki" appears as an anticlerical person 
with negative attitude to the capitalist world and continuously sceptical about the situation in Poland. This is reflected e.g. in the following memes, published among many other texts commenting on current events (changes in open-ended pension funds, burnt rainbow in capital city Plac Zbawiciela square, gender debate in Poland).

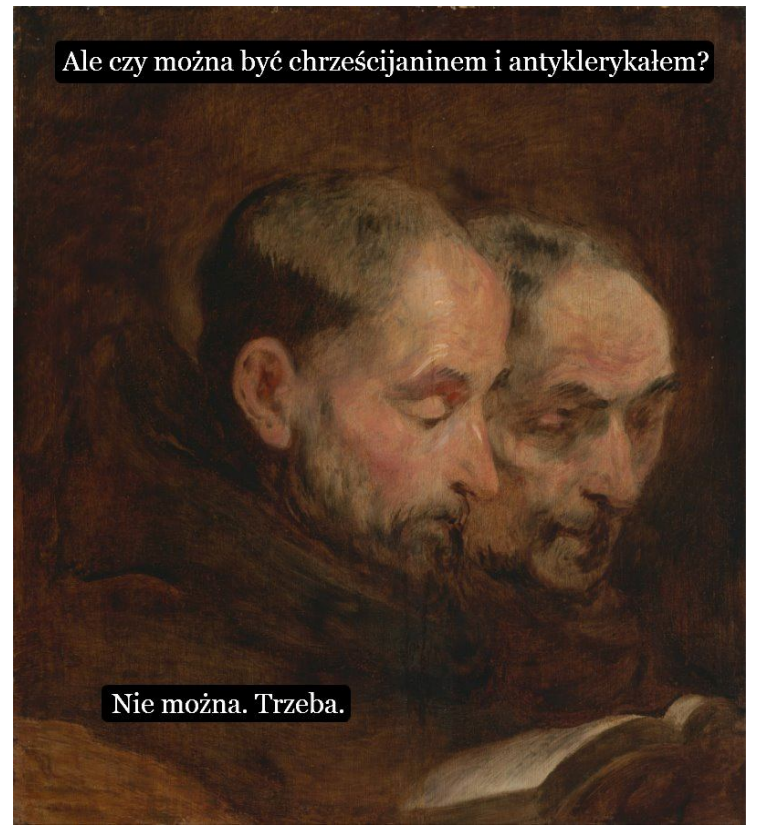

Fig. 3. Meme published at:

https://www.facebook.com/SztuczneFiolki/photos/a.483789074973669.115138.483774998308410/8213636278828 77/?type $=1 \&$ permPage $=1$ [access: May 2016]

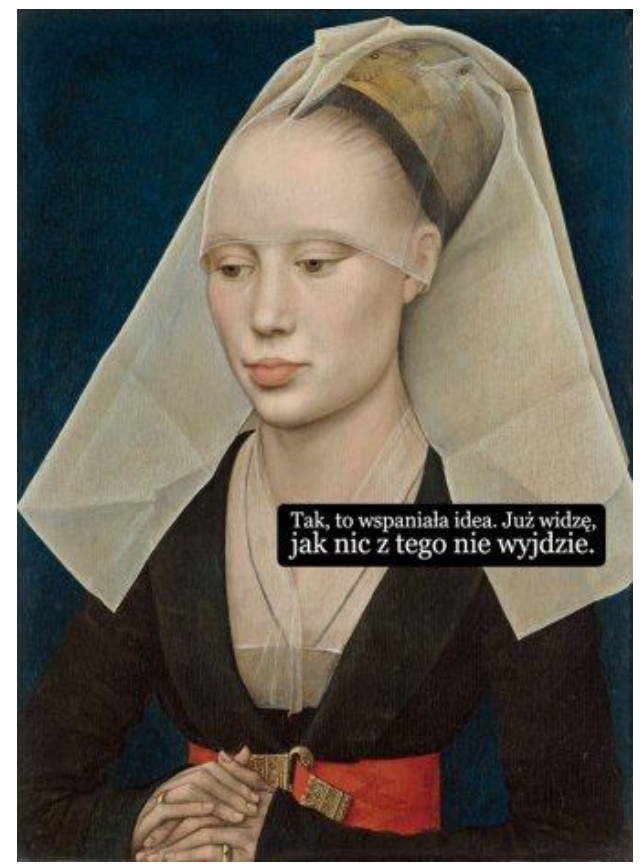

Fig. 4. Meme published at:

https://www.facebook.com/SztuczneFiolki?fref=ts [access: May 2016] 


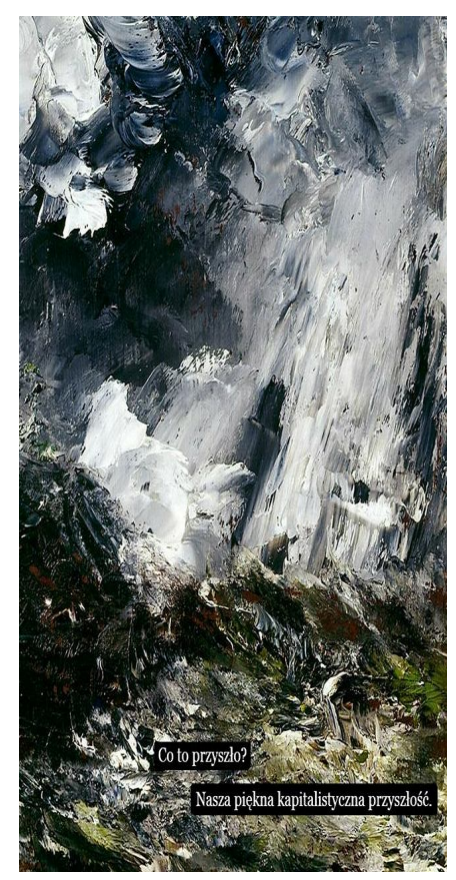

Fig. 5. Meme published at:

https://www.facebook.com/SztuczneFiolki/photos/a.483789074973669.115138.4837749998308410/7313499568842 45/?type $=1 \&$ theater [access: May 2016]

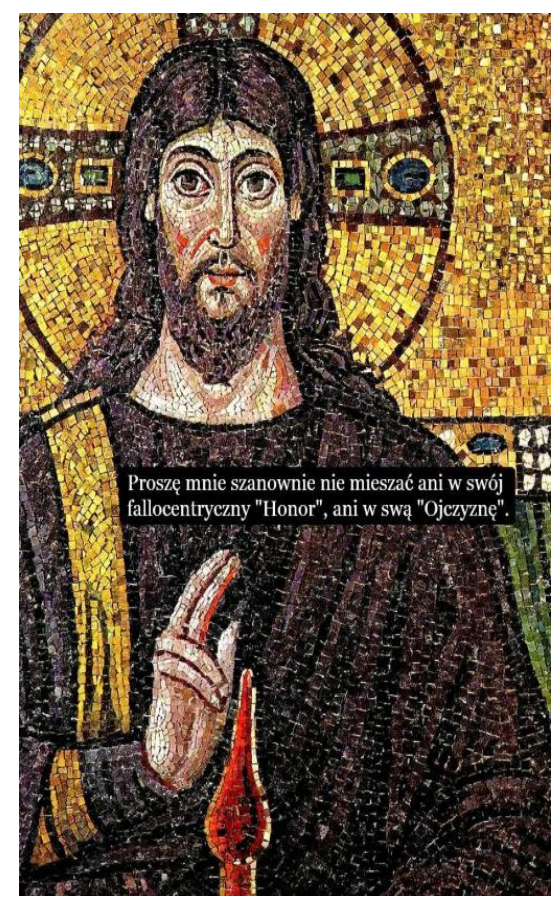

Fig. 6. Meme published at:

http://www.wysokieobcasy.pl/wysokie-

obcasy/1,114377,15498803,Sztuczne_Fiolki_Mam_w_sobie_duze_poklady_wscieklosci.html [access: May 2016]

Apart from new topics and images, published texts include recurring images or characters, such as the painting by George Grosz or Henrie de Toulouse-Lautrec. 


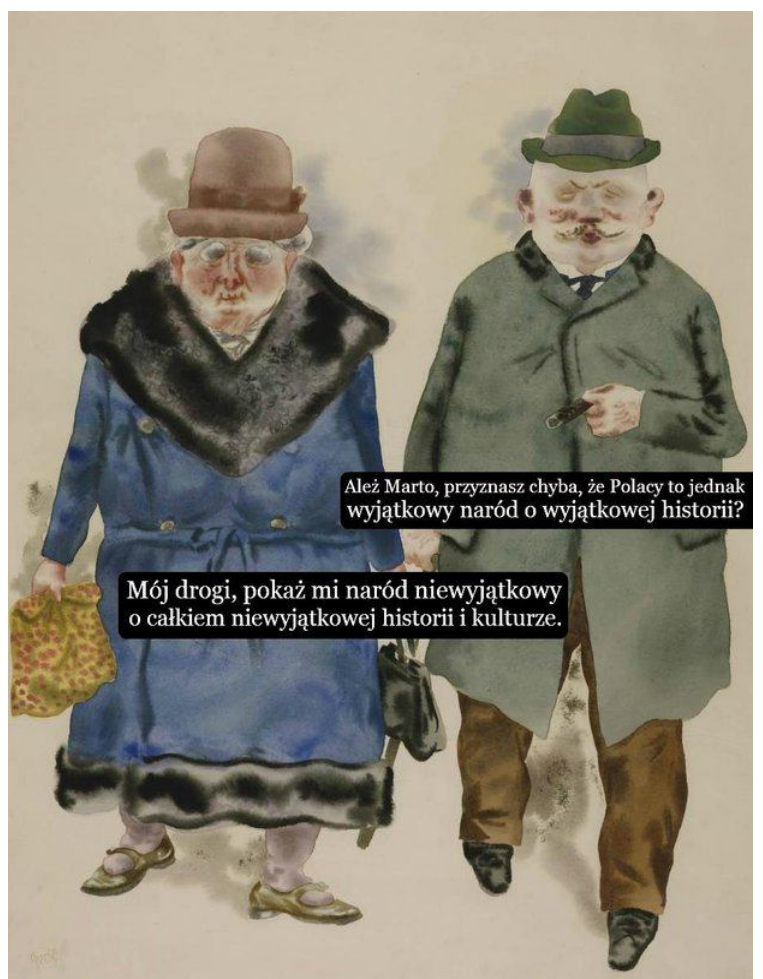

Fig.6. http://wiadomosci.onet.pl/prasa/sztucznefiolki-narzekanie-na-swoj-kraj-to-takze-formapatriotyzmu/j6td4 [access: May 2016]

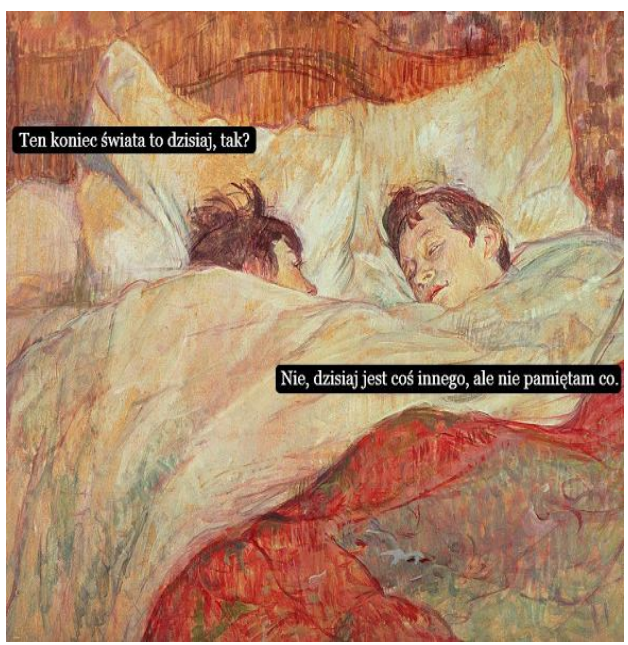

Fig.8. http://culture-

flow.blogspot.com/2012/12/sztuczne-fioki.html [access: May 2016]

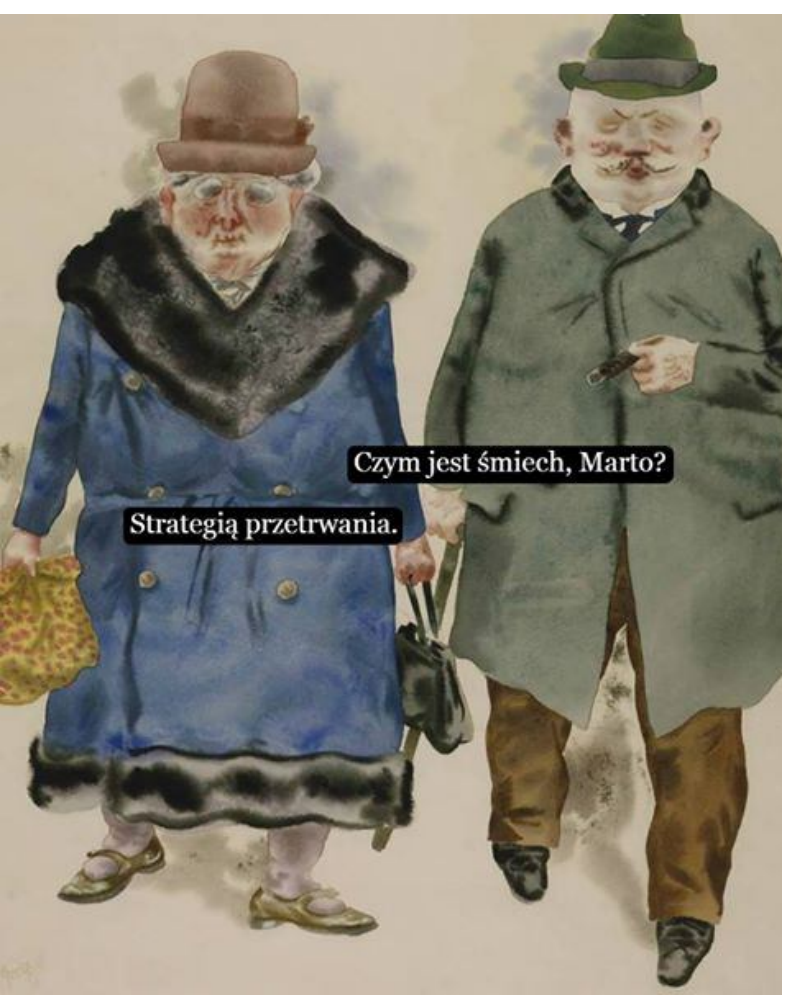

Fig.7.

https://www.facebook.com/SztuczneFiolki/photos/pb .483774998308410 -

2207520000.1409602911./638153552870553

[access: May 2016]

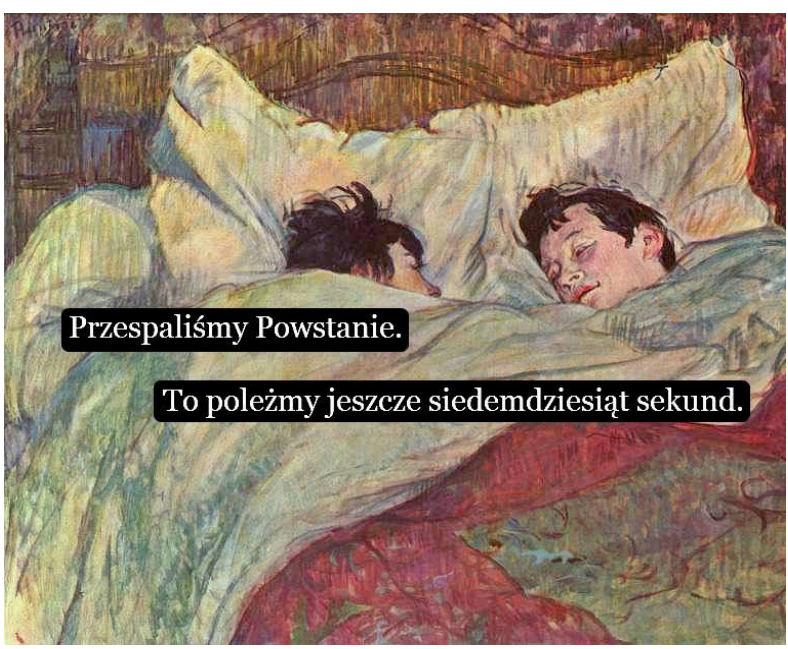

Fig.9.

https://www.facebook.com/SztuczneFiolki/photos/a.4 $83789074973669.115138 .483774998308410 / 822043691$ $148204 /$ ?type $=1$ \&permPage $=1$ [access: May 2016]

Marta is one of the most frequently recurring characters of the posts and seems to be the author's alter ego. The sender has an educational mission, but it is not about promoting art in the mass media. The sender offers critique in the form of a Facebook art meme, which evokes the values of the Enlightenment. As the author explains: "I have recently come to the conclusion that 
Marta is my alter ego. Her opinions are closest to mine. Doesn't Marta like Poland? I think that she dreams of Poland ruled by wise people, and with wise citizens" (Tengowska, 2013). By combining old paintings with present-day statements, the author comments mainly on the situation in Poland. The seriousness of historical painters with current commentary sends a stronger message to Internet users than any treatise from the Age of Enlightenment.

\subsection{RECIPIENT}

The implied recipient of Facebook art meme thematic profiles has both the characteristics of a blog recipient and of a meme recipient. He is interested in the topic, actively searching for originality and novelty. He appreciates uniqueness and even combination of high culture with popular messages as part of an innovative concept, which allows him to get away from mediocrity. He receives a lot of information from many different sources. He comes from the same world as the sender and is part of the community around the Facebook art meme. He is much more concerned with his own image and building his own brand, so he does not enter into a student/master relationship. The relationship between the sender and the recipient is more democratic. It is based on opinion-sharing between equal partners, although the recipient can only affect the shape of the Facebook art meme through his comments, while the author determines its reach, so the roles are asymmetrical. The immanent sender can receive the encoded message, understands the intertextual references, and is encouraged to interfere with the message, engage in its reception, interpretation, future life.

However, he is not as creative and active as the recipient of a meme. Facebook art memes are less dialogic in nature than memes. Fixed location of the message means that its reception is more like consumption than a social game; consumption combined with a recommendation system. The recipient is able to read the ironic and parodying message and the poetic extension of meaning, but does not stimulate his own "ludic, playful spirit" as strongly as in the meme genre. No new, original texts are created as part of the series. The sender remains the chief creative author.

Nevertheless, there are cases where recipients of a fanpage become more engaged in the game and start creating their own works as part of the series initiated by the sender. They post them either on the thematic or their personal profile walls. In terms of scale, this is not as popular as in the case of memes outside of Facebook platforms. The ever-present sender, who started the topic, to a certain degree assumes responsibility for the "production" of content. 


\subsection{MESSAGE}

The analysed Facebook fanpage posts present a more sophisticated form of intertextual and intersemiotic game. "Sztuczne Fiołki" uses mainly classical works, rarely resorting to contemporary art. The author explains this in the following way: "Contemporary art is not really a narration, it does not have characters that look at each other or interact with each other so that we could suggest some kind of dialog between them" (Klimowicz, 2014).

The sender of "Sztuczne Fiołki" uses mainly paintings which Wallis describes as presenting - "replicating", "imagining", "displaying" different real or imaginary objects, also known as "subjective" or "semantic" works (Wallis, 1983, p. 59). They have two layers: the representing layer (lines, spots, coloured shapes) and the layer of presented objects. When the representing layer is concrete (as opposed to abstract, associated with the emergence of Impressionism), it stimulates both our sensitivity and emotionality, and presents in an easily recognizable, "legible" way different items whose iconic elements are clearly marked; in which there is a balance between the representing and stimulating factors" (Wallis, 1983, p. 59). The choice of the painting is the key: the sender contacts the recipient through messages that facilitate reception, which present a concrete and not an abstract reality, where representing elements dominate over the stimulating ones.

Wallis divides works into "independent" ones, which do not require any additional knowledge of art to be fully comprehended, and non-independent ones (Wallis, 1983, p. 60). In most cases, the fanpage publishes independent or well-known works and paintings considered as artistic masterpieces. The aim is to facilitate communication and ensure massive scale. The sender does not have to know the system of code-words in ethnic languages or even recognize the painting. There are scenes of everyday life, nudes, landscapes and still life, provided with semantic enclaves. In order to understand the message of a meme, to experience and receive it, you do not have to be proficient in artistic conventions. In other words, you do not need to be an expert in the art history.

As we have already mentioned in the paragraphs on memes' genesis, the strategy of using images and combining them with words is not a new cultural phenomenon. When analysing "Sztuczne Fiołki", we should review the theses put forward by Mieczysław Wallis, quoted above, concerning texts incorporated into paintings, which the scholar refers to as the "semantic enclaves" of the painting. He defined this separated piece of a different reality as "that part of a work of art which consists of signs of a different kind or from a different system than the signs from which the main body of that work consists" (Wallis, 1983, p. 191). Wallis is interested in such enclaves as inscriptions being invocations, author statements concerning the topic of the 
painting, maxims and $20^{\text {th }}$-century phrases concerning the enrichment and extension of painting meanings, crossing the barriers between different forms of art (including pseudo-inscriptions appearing in the works by Kle or Zbigniew Makowski).

In describing semantic enclaves, Wallis assumes that: "they are autonomous entities within those paintings in which they occur, they have a different semantic structure, they speak a "separate" language. Inscriptions are also a medium for elements of rich and complicated systems of conventional signs to penetrate into the painting... Semantic enclaves of paintings in the form of inscriptions are usually meaningful for a narrower audience than the iconic signs of those paintings"(Wallis, 1983, p. 191).

However, the case of "Sztuczne Fiołki" seems different. The inscription placed in the painting is addressed to mass audience; it is legible and straightforward thanks to its references to an extratextual world. Wallis analysed inscriptions in Western paintings - medieval, modern and contemporary ones. While Facebook art memes use artistic works, they are part of the mass culture. They comment on the offline reality and present artistic works as a material with an element of surprise. A work of art becomes part of a concept, its use strengthens the surprise effect of image and word, their incompatibility or even absurd. It is a confrontation of strikingly different worlds, and that confrontation means that the extremes must engage in a dialogue. They begin to communicate, creating semantic extensions similar to the poetic function of memes.

Hence, we could speak of historical verbal graphy related to high culture on the one hand, and to ludic tradition, currently visible in the mass culture, on the other. The posts on Facebook art memes are periodic in nature, there is a constant sender and, in the case of the analysed profiles, recurring characters (Marta on "Sztuczne Fiołki", "Kot Doktorant" (PhD Student Cat), sophisticated concepts on "Głupie teksty pisane Helveticą" or historical figures on "Facecje"), so we could speak of narration and refer to the theory or history of comics: "The fact that comics first appeared as a humoresque is no co-incidence... Comics offered their readers a world which was not only drawn, but also exaggerated: deformed, overstyled and unmasked in its grotesque form” (Szyłak, 2009, p. 7). Jerzy Szyłak identifies the precursors of comics in the illustrations to the Pickwick Club and in the satirical drawings of William Hogarth (Szyłak, 2009, p. 9). Early traces of comics can also be found in magazine illustrations and zins. Three illustrators played the key role here. The first one was Rodolphe Tópffer (1799-1846), a pedagogue and a writer, who published a cycle of albums with pictures which commented on each other, using the effect of narration and humour. The second important figure was Tőpffer's student, Gustave Doré (1832-1883), who illustrated the works of Rabelais, Byron, Balzac, Dante. He was the first person in the history of comics that used irony in his work. 
In 1854, when he was working on illustrations to The Life of Gargantua and of Pantagruel, he dared to make a graphic joke. He illustrated the Histoire de la Sainte Russie, a work similar to the pictured stories of his mentor, based on perverse, anarchic humour, built on such means as nonsense resulting from the contrast between the meanings suggested by pictures and their captions" (Szyłak, 2009, p. 9). The above quote comes very close to my concept of memes described in previous chapters. Wilhelm Busch (1832-1908) is the third key illustrator in this group. He created several sequential picture stories for Fliegende Blätter, in which, apart from the narration, he focused on presenting movements and emotions (Szyłak, 2009, p. 9).

In the early history of comics, the place and form of publication were of great significance: the fact that they appeared periodically in magazines. "Comics emerged thanks to the emergence of the press, so their existence is closely tied to the mass media", Szyłak says (Szyłak, 2009, p. 10). This resembles the situation of blogs and hobbyist magazines. It is no coincidence that "Sztuczne Fiołki" is described by its author as a "comical-tragic magazine".

Initially, newspaper comics were connected with a story in the form of a one-threaded episode with a punch line, based on situational or verbal humour (Szyłak, 2009, p. 23). Hence the original name of the comics: a comic strip, so comical pictures forming a characteristic strip (Szyłak, 2009). Another name, “cartoon”, was applied to single-picture jokes based on situational or verbal humour (Szyłak, 2009). This, again, seems analogous to Facebook art meme profiles.

The discussion on whether comics can be classified as a form of art has continued up to this day (Beaty, 2012). Most scholars agree that comics are part of the media culture. Jerzy Szyłak takes a clear stand on the matter, writing: "True comics exist outside the cinema or the computer screen, they cannot be broadcast on television. As a work distributed in the form of a booklet, album or newspaper section, they belong to the print culture, which is giving way to electronic media” (2009, p. 130). Perhaps Facebook art memes are something of a comic strip transferred to the new media, at an early stage of its generic journey.

A deeper discussion of the nature of comics exceeds the limits of this work. What we are getting at is the simple conclusion that memoidal Facebook art memes are not based on handmade drawings, they are not a sequence of story-telling frames, and it would be excessive to describe them as picture narration based on the unity of icon and language (Toeplitz, 1985, p. 21). They also fail to meet the criteria currently set by researchers of comics in many other important ways (Szyłak, 2013). Nevertheless, when we refer to the origins of this genre, we can see certain analogies (in terms of functioning and role) connected with the emergence of a new medium (press - in the case of comic strips and now - the Internet), and the needs of the mass audience. Both genres exist within the mass culture, are based on the relationship between 
drawing and writing, are easy to read and have their own poetics (Szyłak, 2000), can be used to convey propaganda or didactic content. As it has been already mentioned, Facebook art memes understood as thematic profiles usually have some entertainment, but also educational purpose. They constitute learning through play, and if that should be too ambitious, they at least encourage reflection.

The first social game resembling the creation of online memes was connected with comics and the "Relax" magazine set up in 1975, described by Stanisław Barańczak as "monotonous" and "fitting the model of socialist mass culture". He wrote: "one can never reconcile the two opposing needs: the persuasion needs of the state (which, in funding the mass media, hopes to gain propaganda effects) and the ludic needs of a society" (Barańczak, 1990). Despite this blatant description, "Relax" brought some innovation in the sphere of communication: it published pictures with bubbles without texts and invited readers to create their own dialogues. The use of known masterpieces instead of comics and encouraging recipients to place their own comments in the bubbles is something that we can currently observe in the activities of the Fala Kultury Association as part of an educational project called "Talking Paintings", which aims to promote art. As the organizers of the campaign explain: "it is a game, but also a way to remind people of the artistic achievements of past decades, forgotten artists and their works... We hope that people will realise that you should become familiar with art already as a child, and that art should not only be associated with dusty museums".

Messages within Facebook art memes are oriented towards a goal related to their topic. The art memes on "Sztuczne Fiołki" ("violets") are an efficient weapon because they violate the principles of appropriateness, confirm that art has been democratised and that every communication participant has the right to use his authority and semiotic message to give it his own, current meaning. The figures in the painting by Gustave Caillebotte talk about jobs in Warsaw, Laurence Stephen Lowry is inspired by dogs and the $14^{\text {th }}$-century painting by Giotto di Bondone mocks Polish antisemitism. 

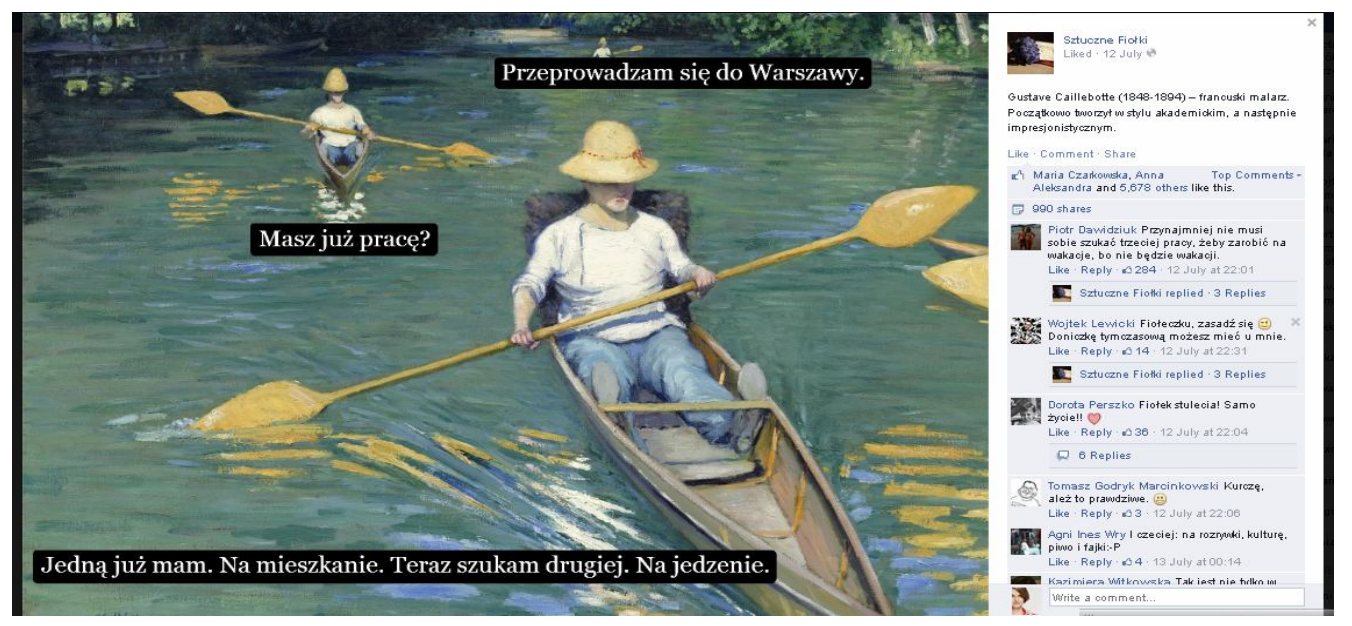

Fig. 10.

https://www.facebook.com/SztuczneFiolki/photos/a.483789074973669.115138.483774998308410/8120562388136 16/?type $=1$ [access: May 2016]

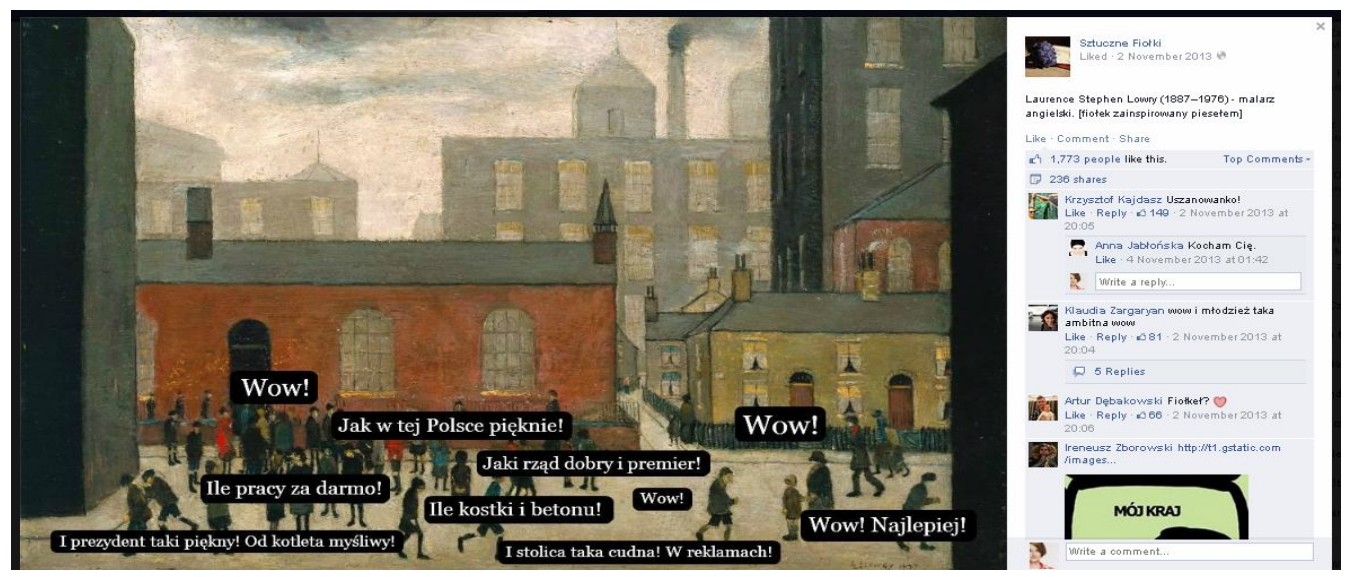

Fig. 11.

https://www.facebook.com/SztuczneFiolki/photos/a.483789074973669.115138.4837749998308410/5696280330564 39/?type=1\&theater [access: May 2016]

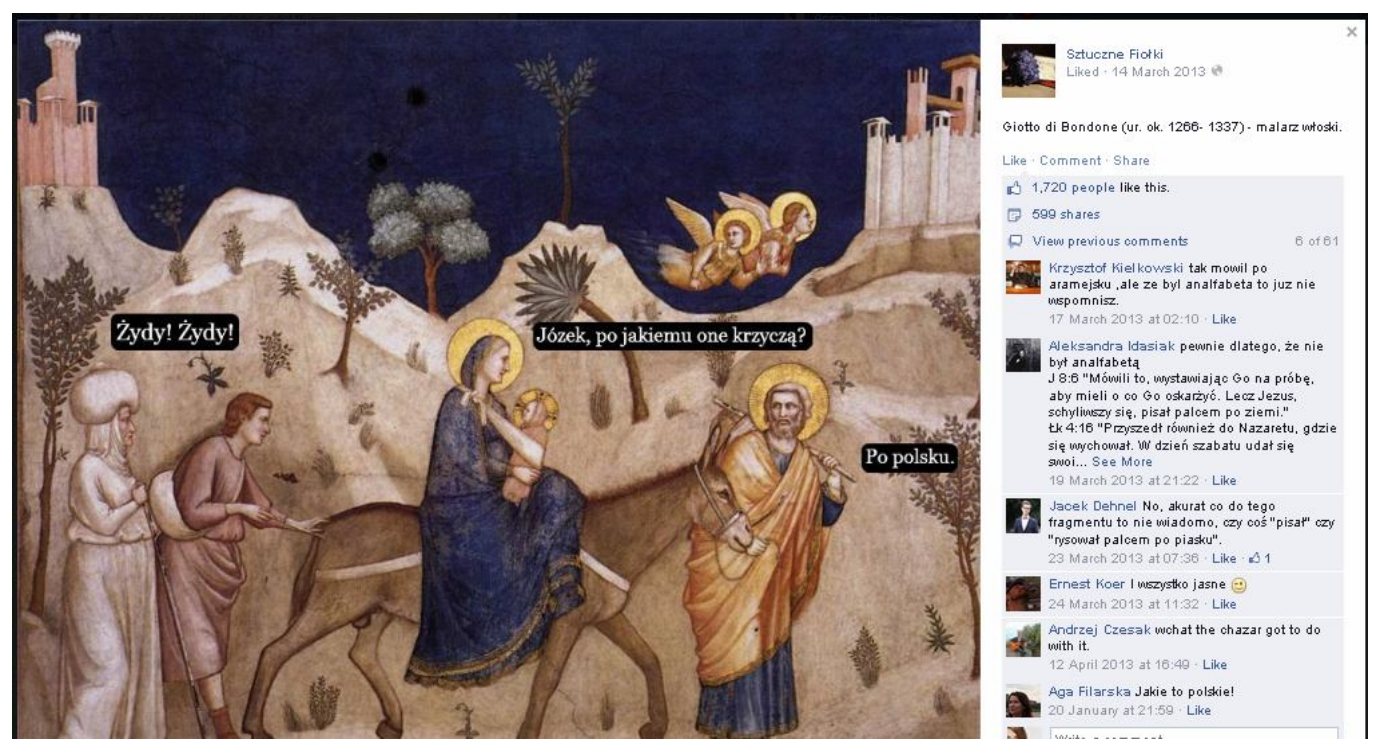

Fig. 12.

https://www.facebook.com/SztuczneFiolki/photos/a.483789074973669.11518.4837749998308410/67799067222017 4/?type=1 [access: May 2016] 
The message on Facebook art meme thematic profile is even more strongly entangled in the interdependencies between two semantic systems (image and word) than other memes. It is less schematic and less repeatable, thanks to more sophisticated intertextual and intersemiotic references. The text in the micro-post, based on previous works of art from a different semiotic order, engages with other texts and modifies them. Intertextual relations can be observed within the text itself, between its various levels, e.g. between the image and the words of the characters. In the case of Facebook art memes, we could speak of a relation of text to text and of text to reality. The message is based on the semantic extension, on the coexistence of and the game between the combination of the given icon and word.

There are more sender platforms, in the form of the author's comment preceding the multimedia text, which is also part of the entire message. Just like in the case of memes, such things as concept, conciseness, clarity, drawing the recipient's attention and standing out from other messages play an important role. The message is humorous and ironic by nature. This contributes to the poetics of the message. The world of media-processed digital images becomes a "natural" communication setting. The message of Facebook art memes functions inside an intricate web of information, among hundreds of thousands of possible information streams. Hence, in order to be heard and stand out, they resort to tricks applied by memes to an even greater extent.

\subsection{CODE}

Just as in the case of comics, in their early days, Facebook art memes use the code of perverse, anarchist language with a tint of irony and a great deal of contradictions. They also provide for confrontation of meanings derived from presented allosemantic messages (in the case of "Sztuczne Fiołki", the given painting evokes different associations than the added commentary; in the case of "Glupie teksty...", a reflective picture is contrasted with down-to-earth commentary) or from the nonsense of the information in the context of our knowledge of the world (knowledge of historical figures and their modernised use).

A painting showing peasants working in the field is provided with a conversation which is inappropriate in the circumstances and concerns an inadequate topic. A peasant wearing leather slippers and with a sickle in his hand explains the concept of gender to his daughter, who is working in the field along his side: "It is a constructed set of attributes, behavioural patterns, perceptions and social expectations as well as norms related to one's biological sex, determining 
the role of a given person in the society and culture as well as his or her status and rights" (Oakley, 1972).

Hence, we could stress the combination of high style with trivial topics, certain parody. In this case, a parody of every-day epiphany, mocking of the "éminence grise of awe". The logovisual text imitates the model, modifying its meaning. The result is ludic, comical. Such playful imitation of clear and recognizable models of stylistic statement structures lends them a completely new colour and new meaning (Nycz, 1995, pp. 199-246). It completely transforms their message. We could speak of the double-coding of messages.

These are just a few examples of contrast used in micro-blogs. Such contrast enables exaggeration, emphasis on the absurd, encouraging reflection. Facebook art memes re-arrange and recontextualize various statement models, leading to the creation of a new, original work structure (formal, thematic and ideological) through dialogic interaction with other texts and their underlying ideas or conventions. Ryszard Nycz distinguishes four functions of parody: the ludic function, which shows off the parodist's skills and reveals the secrets and limitations of the model's style in a humorous way; the satirical function, which mocks and unmasks a certain phenomenon; the critical function and the constructive functions, seen as ancillary to the critical function, aiming to deconstruct or expose the inefficiencies of the targeted convention.

The researcher explains that parody can be a style-forming or a genre-forming phenomenon (Nycz, 1995). In the case of memes one can speak of both the style-forming and the genre-forming dimension. The genre is also connected with situational or verbal jokes which comment on the offline reality. The kinaesthetic mode - capturing movement and emotions makes it even more dramatic. Just as in the case of memes, the selected manner of presenting the given object has both a promoting and an interpreting aspect. Because art memes are more of an author's form, they use ready, conventionalized graphic signs less often than other memes. More sophisticated signs, referring not only to mass culture, but also to high culture, can have a didactic purpose.

\subsection{CONTACT}

Contact within Facebook art memes is the combined form similar to the one known from blogs and memes. Just as in the case of blogs, there are such elements as dialogue, proximity or even familiarity between sender and recipient, and cooperation based on shared interests and opinions. The sender is also the person that determines the ultimate form of the communication, but because the contact is voluntary, he tries to ensure the comfort of the recipient. There is no 
student-mentor relationship. It is more like visiting the website of one's favourite magazine where the reader has the possibility to talk to the author.

Just like other memes, Facebook art memes strive to stand out and be memorable. The message is structured in such a way so as to ensure that the contact is misleading at first, and then reveals the hidden meaning of the message and invites the recipient to engage even further in the communication. However, it does not encourage the recipient to take over the initiative. Once again, we can find an analogy with the origins of the comic strip printed in newspapers: a Facebook art meme is like a micro-magazine, or a column devoted to logo-visual, humorous commentary of the reality. This is why the violets are also a successful recurring column of newspaper's supplement in the offline world.

\subsection{CONTEXT}

Intertextuality has already been mentioned several times in reference to memes, in the immanent context of the communication setting of Facebook art memes. The memoidal thematic profiles are intertextual constructs referring both to high culture and to topics known mainly from mainstream mass media. They combine different stylistic (high style and low style) and semantic (image and word) orders. The word does not have a dominant function; it is a carrier of meaning of equal importance to the word.

Facebook art memes use sociolects understood "not as grammar and vocabulary, but as a warehouse of social myths. They are represented through topics, circulating phrases and descriptive systems (stereotypical metonymy networks around a given lexical nucleus)" (Riffaterre, 1995, p. 107). This is why their reception does not require professional knowledge. Ryszard Nycz talks about intertextuality in the context of mediatisation. He points out that the frame plays the most important role in this process (1995, p. 107). The frame can be famous paintings ("Sztuczne Fiołki”), symbolic photos and poetry quotes (“Głupie Teksty...”), the PhD Student Cat ("Jesteś Kotę...”) or well-known historical figures ("Facecje”). A frame provides for repeatability, prefabrication, it is a basic element of intertextual processes. "Analysed without reflection, it ensures: transparency (thanks to homogeneity), probability (as a factor of consensus, dox), objectivity of presentation (because its typifying properties enable the identification of the object regardless of the circumstances or points of view: it acts as the structural invariant). Analysed critically, it is the basic material for meaning regeneration techniques (such as disautomation and estrangement), the tools of parody, the strategy of "unmasking the tricks" of realistic illusionism in meta-novel forms, intertextual collage etc. These properties make it "easy to put together", ready to use under various writer strategies" (Nycz, 2000). In the case of 
Facebook art memes, it is not only about references to other texts, but also about the extratextual relations with social, historical and cultural reality.

Hence, we could say that Facebook art memes borrow certain migrating form-shaping elements from blogs and memes. Those derived from blogs are connected with the cyclical nature of publications; rooting of the communication in one place; metatextual elements. Moreover, memes resemble blogs in that they discuss specific topics corresponding to the name of the profile (global vision); the topics of neighbouring posts are related; there is constant dialogue with the recipients; the author has a subjective opinion on the problems discussed. The elements borrowed from memes include: concept (surprise effect), distance to the presented world reflected in a mocking ethos (comedy and parody), structure, which helps memorising the text and encourages its sharing, intertextual and intersemiotic references. However, many features of blogs and memes cannot be realized in a Facebook art meme, and those which can, have their own, specific dimension, due to confrontation of different messages. This is why a Facebook art meme, as a form of communication, transforms the specific characteristics of a blog, such as the dominant position of the author (personal perspective), the resulting media intimacy and characteristics of memes related to participation in a game. Compared to memes, the sender of a Facebook art meme is not as clearly defined, with no references to his personal life, and is not as strongly engaged in the creation of a text series. It is more of a "reading" genre, for sharing with others something one has found, and for pursuing one's own instant creativity.

As a rule, local Facebook art memes are more refined and "sophisticated" as compared with the memes circulating on the Internet. It also seems that they are created with greater awareness as to the use of allosemantic messages.

\section{FACEBOOK ART MEMES IN POLISH MEMOSPHERE AS LOCAL RECEPTION OF GLOBAL DIGITAL FORM}

The genre characteristics appear with different intensity in different online genre-communication forms. We could speak of genologic gradation, which may be key to understanding the different characteristics of each particular online genre, although all of them look for models in a common base of elements. For example, the sender is most exposed (in terms of the degree of dialogue) in the genre of blogs, and least exposed in memes (degree of spontaneity, situationality). The recipient is most strongly motivated to act by the text in memes (degree of spontaneity, situationality), and least strongly in blogs.

Generally, as any online genre, Facebook art memes have multimedia, dialogic (resembling a familiar conversation) features. They are spontaneous, situational (highly 
referential) and based on the immediacy of mutual relationship between the sender and the recipient. Memes differ from other semantic forms in their relationship between image and word. Facebook art memes are based on the play between contrasts, contradictory meanings (polemic relationship). This is one of the reasons why we can speak of their dominant poetic function.

The most important characteristics of Facebook art memes include: using the effect of surprise, concepts which should surprise the recipient, incorporating the message into a web of intertextual relations and irony and distance towards the presented world. As part of this genre, the sender controls the message. There is irony and humour, confrontation of image and the world, which leads to semantic extension. Appropriate reception of a message requires the recognition of cultural frames and abstract thinking. The image is usually kinaesthetic and captures an emotional moment. The image, which is part of the text, illustrates a symbolic gesture, can be inscribed in the iconography as a carrier of specific feelings, becomes a convention. It seems like a distant echo of pathos formulae (Pathosforme) formulated by Aby Warburg, a precursor of visual culture. The term refers to an illustrated gesture based on a load of mental energy flowing from primary experience ${ }^{1}$. The entire message must be concise, oriented towards capturing and maintaining the recipient's attention, often through a surprising punch line. It is a provocative, spontaneous interaction. The concise or even mnemotechnical message employs different cultural texts.

What is characteristic about the local Polish version of Facebook art memes analysed above? It turns out that their strength comes from the combination of their reach, impact and quality of performance. In other words: the localised global genre-communication form has aptly addressed the needs of the local population of digital media (and other) media recipients. Their genological characteristics have occurred more and more suitable for the new audiences: "Sztuczne Fiołki" appeared in 2012, in August 2014 had nearly 89 thousand fans and 159 thousand fans in May 2016.

"Sztuczne Fiołki" is referred to as a cultural phenomenon on the Polish Internet. In 2012, the profile was nominated for "Polityka's" Passport award in the visual art category (Sarzyński, 2012). This competition aspires to be one of the most prestigious awards in Poland and has honoured distinguished authors of literature, films, popular music, art music, visual art and theatre since 1993. The popularity of "Sztuczne Fiołki" is also studied by art historians. As Dorota Lagodzka comments: “Typical of postmodernism, of Dadaistic origin and pop culture

\footnotetext{
1 More at: Warburg, A. (1999). Wstęp do Mnemosyne, Warburg Archive, no. 102.I.I.6. In: M. Rampley (ed.), Archives of Memory:Walter Benjamin's Arcades Project and Aby Warburg's „Mnemosyne Atlas”. In: A. Coles (ed.), The Optic of Walter Benjamin. London: Black Dog Publishing. p. 105; Rampley, M. (1997). From symbol to allegory: Aby Warburg's theory of art. Art Bulletin, vol. 79*; Rampley, M. (2000). The Remembrance of Things Past. On Aby M. Warburg and Walter Benjamin. Harrassowitz: Wiesbaden.
} 
affiliations, a sister to found footage, a cousin to pop art... appropriation art. (I am not fond of this concept; another English neologism in the Polish art history, which finds it hard to cope with terminology). They may be seen as a form of online culture, the art of mass production of memes, making jokes mixed with constructive criticism and social commentary through works of art. Profanity, to the extent that Dadaism was profanity" (Lagodzka, 2012).

However, the media widely commented on four memes from "Sztuczne Fiołki" gone missing from an exhibition during the ART.eriawe festival in September 2013. Ten images were displayed along the avenue leading to Jasna Góra. The four lost ones were later found at the episcopal curia, and the spokesman argued that they had disappeared from the exhibition because they offended religious feelings (Piersiak, 2013). In this context it is worth noting that even Facebook team themselves have shut down the profile twice. The first time, probably due to the system's misunderstanding of the ironic message - the moderators probably classified one of the paintings as pornography and Nazi content.

Despite that, restored "Sztuczne Fiołki" Facebook art memes fanpage is highly popular and was even transferred offline - there are exhibitions of the memes and publications in "Duży Format", a supplement to "Gazeta Wyborcza". This is one of the rare instances where an online genre-communication form is procured by editors of high-circulation opinion-forming nationwide newspaper. Thus, the art of painting remediated in digital forms of so-called "memes" illustrates the global flow from the Western centre to the Eastern semi-peripheries of digitalizing Euro-Atlantic civilization.

While the inner structure of "art memes" may be similar regardless of their origin and language, there is an unbridged difference in their local semantic details. It leads to differences in reception and in influence on collective imaginations, debates and opinions. Undoubtedly, Polish Facebook art memes are the example of flow from West to East, which results in local enrichments of the global medium and content. Why does it follow this direction - and could there have been similarily semantically rich local Facebook art memes not preceded by those of Western origin? This question remains to be investigated further.

At least some parts of the Polish memosphere, as illustrated by Facebook art memes, reveal mechanisms of global form's local reception. However, the analysis of the emerging genre of Facebook art memes in Poland leads to the conclusion that even the new genres can be exceptional in their local role of public opinion-forming. With their partially global, and in part locally developed inner structures, they can be more successful than the examples of the same genre preceding them. This mechanism also remains to be investigated further. 


\section{REFERENCES}

All online links valid in May 2016.

Bachtin, M. (1986). Estetyka twórczości stownej. Warszawa: Państwowy Instytut Wydawniczy.

Balbus, S., Hejmej, A., Niedźwiedź, J. (2004). Intersemiotycz̨ność: literatura wobec innych sæztuk (i odwrotnie). Kraków: Towarzystwo Autorów i Wydawców Prac Naukowych "Universitas".

Balbus, S. (2000). Zagłada gatunków. In: W. Bolecki, I. Opacki (ed.), Genologia drisiaj. Katowice:Wydawnictwo Instytutu Badań Literackich PAN.

Balbus, S. (2007). Zagłada gatunków. In: R. Cudak, D. Ostaszewska (ed.), Polska genologia literacka. Warszawa: Wydawnictwo Naukowe PWN.

Balcerzan, E. (1999). Nowe formy w pisarstwie i wynikające stąd porozumienia. In: J. Koziecki (ed.), Humanistyka przetomu wieków. Warszawa: ŻAK Wydawnictwo Akademickie. Balcerzan, E. (2000). W stronę genologii multimedialnej. In: W. Bolecki, I. Opacki (ed.), Genologia drisiaj. Katowice:Wydawnictwo Instytutu Badań Literackich PAN.

Balcerzan, E. (2007). W stronę genologii multimedialnej. In: R. Cudak, D. Ostaszewska (ed.), Polska genologia literacka. Warszawa: Wydawnictwo Naukowe PWN.

Barańczak, S. (1990). Ksiqżki najgorsze i pare innych ekscesón krytycznoliterackich. Kraków: Znak.

Beaty, B. (2012). Comics versus Art. Toronto: University of Toronto Press, Scholarly Publishing Division

Bolecki, W. (2007). O gatunkach to i owo. In: R. Cudak, D. Ostaszewska (ed.), Polska genologia literacka. Warszawa: Wydawnictwo Naukowe PWN.

Bolter, J., Grusin, R. (2000). Remediation: understanding new media. Cambridge: The MIT Press.

Boyd, D. (2006). A Blogger's Blog: Exploring the Definition of a Medium. Reconstruction, 6 (4). Retrieved from: http://www.danah.org/papers/ABloggersBlog.pdf

Cudak, R. (2007). Rzut oka na polska genologię literacką. In: R. Cudak, D. Ostaszewska (ed.), Polska genologia literacka. Warszawa: Wydawnictwo Naukowe PWN.

Cywińska-Milonas, M. (2002). Blogi (ujęcie psychologiczne). In: P. Marecki, Liternet. Literatura i internet. Kraków: Rabid.

Dawkins, R. (1996). Samolubny gen. Warszawa: Prószyński i S-ka.

Gajda, S. (2001). Gatunkowe wzorce wypowiedzi. In: J.Bartmiński (ed.), Wspótczesny jezylk polski. Lublin: Wydawnictwo UMCS Lublin.

Chen, C. (2012). The Creation and Meaning of Internet Memes in 4Chan: Popular Internet Culture in the Age of Online Digital Reproduction. Retrieved from: http://www.yale.edu/habitus/habitus_design_6.625_\%283\%29.pdf\#page=6.

Gill A., Nowson S., Oberlander J. (2009). What Are They Blogging About? Personality, Topic and Motivation in Blogs. In: Proceedings of the Third International ICWSM Conference, San Jose: The AAAI Press. 
Giltrow, J. (2001). Meta-Genre. In: R. Coe, L. Lingard, T. Teslenko (ed.), The Rhetoric and Ideology of Genre: Strategies for Stability and Change. Cresskill: Hampton Pr.

Grochowski, G. (2000). Hybrydy tekstowe. Literackość i jej pogranicza. Warszawa: Wydawnictwo Naukowe Uniwersytetu Mikołaja Kopernika.

Grzenia, J. (2006). Komunikacja jezykowa w Internecie. Warszawa: Wydawnictwo Naukowe PWN.

Gumkowska, A., Maryl, M., Toczyski, P. (2009). Blog to...blog. Blogi oczyma blogerów. Raport z badania jakościowego zrealizowanego przez Instytut Badań Literackich PAN i Gazeta.pl. In: A. Gumkowska (ed.), Tekst (w) sieci t. 2. Literatura. Spoteczeństwo. Komunikacja. Warszawa:Wydawnictwa Akademickie i Profesjonalne.

Gumkowska, A. (2009). Tekst(w)sieci. Warszawa: Wydawnictwa Akademickie i Profesjonalne.

Gumkowska, A., Toczyski, P. (2016). New digital genre communication forms as an area.

Revealing digital competences. In: Ł. Jonak, N. Juchniewicz, R. Włoch (eds.), Digital Ecosystems. Society in the Digital Age. (pp. 17-32). Warszawa: University of Warsaw.

Hare, P., Jones, D., Blackledge G. (2007). Understanding social enterprise: a case study of the childcare sector in Scotland. Social Enterprise Journal, Vol. 3 Iss: 1, pp. 113 - 125.

Hatalska, N. (2013). Fanpage Natalii Hatalskiej Hatalska.com. Retrieved from: https://www.facebook.com/hatalska.com/posts/10151324970862409.

Hopfinger, M. (2003). Doświadcz̧enia audiowizualne. O mediach w kulturze wspótczesnej. Warszawa: Sic!

Juza M. (2013), Memy internetowe - tworzenie, rozpowszechnianie, znaczenie społeczne, Studia Medioznawcze, 4 (55).

Kamińska M. (2011). Niecne memy. Dwanaście wykładów o kulturze Internetu. Poznań: Galeria Miejska Arsenał.

Klimowicz J. (2014). Sztuczne Fiołki: mam w sobie duże pokłady wściekłości. Retrieved from: http://bialystok.wyborcza.pl/bialystok/1,35235,15498803,Sztuczne_Fiolki_Mam_w_sobie_duz e_poklady_wscieklosci.html

Knobel, M., Lankshear C. (2007). A new literacies sampler. Nowy Jork: Peter Lang Publishing Inc.

Kołowiecki W. (2012). Memy internetowe jako nowy język Internetu. In: Kultura i Historia, nr 21 Retrieved from: [online] http://www.kulturaihistoria.umcs.lublin.pl/archives/3637.

Laurent, J. (1999). A Note on the Origin of 'Memes'/'Mnemes'. Journal of Memetics - Evolutionary Models of Information Transmission, nr 3, pp. 20-21. Retrieved from: http://cfpm.org/jomemit/1999/vol3/laurent j.html.

Lejeune, P. (2001). Wariacje na temat pewnego paktu. O autobiografii. Kraków: Towarzystwo Autorów i Wydawców Prac Naukowych "Universitas". Lagodzka, D. (2012). Sztuczne Fiotki, Sroka i koty, Retrieved from: http://niezlasztuka.blogspot.com/2012/12/sztuczne-fioki-sroka-i-koty.html

Marecki, P. (2003). Liternet.pl. Kraków: Rabid.

Maryl, M. (2010). Technologie literatury. Wpływ nośnika na formę i funkcje przekazów literackich. Pamietnik Literacki, 2 (101), pp. 157-178.

McLuhan, M., Lapham, L. (1994). Understanding Media: The Extensions of Man. New York: The MIT Press. 
Milewski, J., Toczyski, P. (2009). Jak badaliśmy? Metodologia i przebieg badania. [in:] K. Krejtz (ed.), P. Toczyski (proj. coord.), J. Milewski (tech. coord.). Diagnoza Internetu 2009, Warszawa: Wydawnictwa Akademickie i Profesjonalne.

Nycz, R. (1995). Tekstowy świat. Poststrukturalizm a wiedz̧a o literaturze. Warszawa: Instytut Badań Literackich.

Oakley, A. (1972). Sex, Gender and Society. London: Temple Smith.

Okopień-Sławińska A. (1987). Relacje osobowe w literackiej komunikacji. In: H.Markiewicz, Problemy teorii literatury, t. II. Wrocław: Ossolineum

Piersiak, T. (2013). Kuria częstochowska "aresztuje" "Sztuczne Fiołki". Bo były telefony. Retrieved from: http://wyborcza.pl/1,76842,14651166,Kuria_czestochowska_aresztuje__Sztuczne_Fiolki_.ht $\mathrm{ml}$

Sarzyński P. (2012). PASZPORTY 2012. Nominacje w kategorii SZTUKI WIZUALNE. Retrieved from: http://www.polityka.pl/tygodnikpolityka/paszporty/1532733,1,paszporty-2012nominacje-w-kategorii-sztuki-wizualne.read

Semon, R. (1909). Die mnemischen Empfindungen in ibren Beriebungen zu den Originalempfindungen. Leipzig: W. Engelmann.

Shifman, L. (2013). Memes in Digital Culture. Cambridge: MIT Press.

Shifman, L. (2013). Memes in a Digital World: Reconciling with a Conceptual Troublemaker. Journal of Computer--Mediated Communication, nr 18, pp. 362-377. Retrieved from: http://onlinelibrary.wiley.com/doi/10.201111/jcc4.12013/full

Skwarczyńska, S. (1932). Škice z zakresu teorii literatury. Lwów: Wydawnictwo Zakładu Narodowego im. Ossolińskich.

Skwarczyńska, S. (1966). Teoria badań literackich za granica: antologia. T. 1, Romantyzm i pozytywizm. Cz. 2, Kierunki pozytywistyczne, krytyka subiektywna i kierunki postposytywistyczne. Kraków: Wydawnictwo Literackie.

Jurewicz, O. (ed., 2001). Stownik Grecko-Polski. Warszawa: Wydawnictwo Szkolne PWN.

Szczęsna, E. (2007). Poetyka mediów. Polisemiotycæ̋ność, digitalizacja, reklama. Warszawa: Wydział Polonistyki Uniwersytetu Warszawskiego.

Szyłak, J. (2000). Poetyka komiksu. Warstwa jezykowa i ikoniczna. Warszawa: Wydawnictwo słowo/obraz terytoria.

Szyłak, J. (2013). Komiks w sapponach miernoty: rozpprawy i škice. Warszawa: Timof i Cisi Wspólnicy.

Tengowska, M. (2013). Sztuczne fiołki: narzekanie na swój kraj to także forma patriotyzmu. Retrieved from: http://wiadomosci.onet.pl/prasa/sztuczne-fiolki-narzekanie-na-swoj-kraj-totakze-forma-patriotyzmu/j6td4

Toczyski, P., Kustra, A., Rzeźnik, J., Gerszewska, M., Wilmowska, I., Borys, Ł. (2012). World Internet Project. Poland 2012. Warsaw: Agora S.A. \& TP Group.

Toeplitz, T. (1985). Sztuka komiksu. Warszawa: Czytelnik.

Trammell, K., Tarkowski, A., Hofmokl, J., Sappy, A. (2006). Rzeczpospolita blogów: Examining Polish bloggers through content analysis. Journal of Computer-Mediated Communication, 11(3), pp. 702-722.

Wallis, M. (1983). Sz̨tuki $i$ qnaki. Pisma semiotyczne. Warszawa: Państwowy Instytut Wydawniczy.

Więckiewicz, M. (2012). Blog w perspektywie multimedialnej. Toruń:Wydawnictwo Adam Marszałek. 
Witosz, B. (2002). Gatunek-sporny (?) problem współczesnej refleksji tekstologicznej. In: W. Bolecki, R. Nycz (ed.), Sporne $i$ bezsporne problemy wspótczesnej wiedæy o literaturz̨e. Warszawa: Wydawnictwo Instytutu Badań Literackich PAN.

Winer, D. (2004). The history of weblogs. Weblogs.com. Retrieved from: from http://newhome.weblogs.com/historyOfWeblogs

Wójcik, A., Dryll E. (2008). Formalna analiza języka blogów - prezentacja metody. In: B. Janusz, K. Gdowska, B. de Barbaro (ed.), Narracja. Teoria i praktyka. Kraków: Wydawnictwo Uniwersytetu Jagiellońskiego. 